\title{
Effect of Flutamide in Mouse Spermatogenesis and on the Function of Seminal Vesicle and Prostate
}

\author{
Efecto de la Flutamida en la Espermatogénesis del Ratón y \\ en la Función de la Vesícula Seminal y Próstata \\ "Eduardo Bustos-Obregón; ***Pedro Esponda \& *Luis Sarabia
}

BUSTOS-OBREGÓN, E.; ESPONDA, P. \& SARABIA, L. Effect of flutamide in mouse spermatogenesis and on the function of seminal vesicle and prostate. Int. J. Morphol., 24(2):171-174, 2006.

SUMMARY: The spermatogenesis is regulated by the hypotalamus-hypophysis gonadal axis, and the androgens play a fundamental role in their last stages. The administration of the antiandrogen flutamide interferes with the function of androgen dependent organs (Prostate (P) and Seminal Vesicle (VS)). In this study flutamide (10mg/Kg b.w.) was injected to 10 mice and vehicle to the controls (n=6). The mice were sacrificed at $24(\mathrm{n}=5)$ and $72(\mathrm{n}=5)$ hours. In testicular sections the tubular diameter (TD) and height of seminiferous epithelium (EH) were measured. P and VS were macerated, and concentrations of fructose (VS) and zinc (P) were determined. No significant difference exists in the DT among the groups. However, the $72 \mathrm{hrs}$ group showed EH higher than the control $(\mathrm{p}<0.01)$. The fructose is lower at $72 \mathrm{hrs}(\mathrm{p}<$ $0.01)$ interval, at which the biggest concentration of zinc is found $(\mathrm{p}<0.01)$. The decrease of the EH could be explained by the detachment of the elongated espermatids, due to the blockade effect on the testosterone activity, without being reflected in the TD at this short interval. The decrease of fructose clearly shows the deprivacion of androgens, whereas the elevated concentration of prostatic $\mathrm{Zn}$ at $72 \mathrm{hrs}$ suggests deficiency in the secretion of $\mathrm{Zn}$ to the seminal plasma.

KEY WORDS: Flutamide; Mouse; Spermatogenesis; Seminal vesicles; Prostate.

\section{INTRODUCTION}

The spermatogenesis is the sum of the processes that finish with the production in the adult sperm. Along this process, we can observe different cellular types: spermatogonia, spermatocytes and spermatids that finally will give origin to the spermatozoa (Arrau et al., 1975).

In mouse spermatogenesis 12 stages have been described. In a cross section of seminiferous tubules only one of these stages is appreciated (Arrau et al.).

Diverse studies have reached to the conclusion that the hormonal regulation of the spermatogenesis is in charge of a complex system, the hypothalamus-hypophysis-gonadal axis. Specific hormones participate in each level and in turn, they are regulated by a negative feedback system. The hypothalamus as first step secretes releasing factors which stimulate the hypophysis with the consequent liberation of gonadotrophins: LH and FSH. The first one acts on the Leydig cells in the intertubular compartment, stimulating the production of testosterone. In turn the Leydig cell presents two sistems of negative feedback pathways, one acts inhibiting the production of LH in the hypophysis and the other one inhibiting the synthesis of testosterone. On the other hand, the function of FSH has not been determined with certainty. It is believed that it would participate regulating the early developmental periods of the spermatogenesis, and its production would also be regulated by a system of negative feedback by a molecule liberated via the Sertoli cells called inhibin (Arrau et al. and Steinberger, 1975).

The Sertoli cell, considered as a nurse cell for the germinal cells, elaborates a protein binder of androgens (ABP) that would be a facilitator to transfer testosterone to a receiving germinal cell.

The androgens fullfil a fundamental and indispensable role in this process. Their effect is achieved by means of

\footnotetext{
" Universidad de Chile. Escuela de Medicina. ICBM. Santiago, Chile.

** Centro de Investigaciones Biológicas. CSIC. Madrid, Spain.

Grant DI 04/15-2, Universidad de Chile, Chile.

This paper is dedicated to Prof. Dr. M. Davidoff, on the occasion of his 65th birthday.
} 
the binding to androgen receptors(AR) that promotes genomic activity, thus acting as transcription factors.

There are two types of AR (A and B) being this last one preponderant in all tissues. The site of binding to the ligand is the carboxyl end and adjacent to this, the site binds to the DNA. The differences among the two receptors are in the amino end (Wilson \& McPhaul, 1996).

The binding of the androgens to the receptor causes two conformational changes that allow the migration and binding to the DNA. These changes involve two segments of the carboxyl end of different molecular weights, $35 \mathrm{KDa}$ and $29 \mathrm{KDa}$, related each one respectively with a change (Brinkmann et al., 1999).

One of the methods utilized to study the effect of testosterone in their target cells, is the administration of antiandrogens like flutamide, a non esteroidal molecule, In the organisms, this molecule is metabolized to 2hidroxyflutamide and it blocks the receptors competitively with effects similar to those provoked by nilutamida (Brodgen \& Clissold, 1989). The union of flutamide to the AR causes inactivation of receptors by producing a conformational change (35KDa), avoiding the participation of testosterone in the cellular processes (Brinkmann et al., 1999). The receptors for androgens in the hypothalamus are blocked by flutamide, which interrupts the negative feedback for release of LH and testosterone resulting in a temporary increment in the secretion of LH and as a consequence, an increase in the production of testosterone (Viguier-Martínez, 1983).

In other organs, the effect is also appreciated in its functionality. The prostate, contrary to other tissues, concentrates high levels of zinc, indispensable element for enzymatic activities and gene expression. Studies in rats have demonstrated that the prostatic accumulation of zinc is regulated by testosterone and prolactin (Costello et al., 1999).

In the case of the seminal vesicle, the secretion of diverse substances to the seminal pathway is necessary to generate a normal sperm motility. One important substance is fructose, a monosaccharide that participates in the metabolic energetic route. It is synthesized and secreted by the vesicle. It has been determined that their synthesis is regulated by androgens and it is correlated directly with the levels of testosterone (Gonzales, 1991).

In this investigation, flutamide will be injected to male mice to be able to determine the changes taking place in the presence of this antiandrogen in the concentrations of zinc in prostate, fructose in seminal vesicle and in the development of spermatogenesis in mice.

\section{MATERIAL AND METHOD}

Sixteen male mice 3 months old were used. In the experimental group 10 mice were used that received pure flutamide provided by Laboratory Tecnofarma, Santiago, Chile.

The mice were injected with pure flutamide with a single dose, intraperitoneally $(10 \mathrm{mg} / \mathrm{Kg}$ of body weight, in a volume of $200 \mathrm{ml})$. The control group $(\mathrm{n}=6)$ received corn oil in the same volume ( $200 \mathrm{ml})$, also by intraperitoneal administration.

The mice were sacrificed at $24(\mathrm{n}=5)$ and $72(\mathrm{n}=5)$ hours starting from the intraperitoneal administration of each compound.

Testicular samples for routine procedures for optic microscopy were used and sections were stained with Periodic Acid Schiff - Hematoxylin (PAS-H). For each animal and case 50 cross sections were measured and evaluated for two histometric characteristics of the seminiferous tubules: height of the germinal epithelium (EH) and diameter of the tubules (TD). These measures were obtained using the computational program Image Tool (Image Tool version 3.0).

To evaluate the accessory organs, $3 \mathrm{ml}$ of distilled water were added to the samples of tissue before macerating them.

To determine the concentrations of fructose in seminal vesicle (Gonzales, 1991), they were macerated and centrifugated at $5000 \mathrm{rpm}$, during 10 minutes. $10 \mathrm{ml}$ of supernatant was adjusted to $1 \mathrm{ml}$ to which $0.5 \mathrm{ml}$ of resorcinol was added and then $1.5 \mathrm{ml}$ of $\mathrm{HCl}$. The solution stayed at $80^{\circ} \mathrm{C}$ for 12 minutes. The reaction with resorcinol originates a rosy color that was read at $500 \mathrm{~nm}$. The calibration chart was carried out diluting a well-known concentration of fructose in benzoic acid.

The colorimetric method for the determination of zinc in the prostate is based on the reaction between the zinc and the 4-(2-piridilazo) resorcinol in a solution buffered to $\mathrm{pH}$ 9.5 (Gonzales, 1991). Macerated prostatic tissue was centrifuged at $3000 \mathrm{rpm}$ during 10 minutes. Then $200 \mathrm{ul}$ of supernatant were placed in 2 flasks plus $1 \mathrm{ml}$ of concentrated $\mathrm{HClO}_{4}$ added. After 10 minutes. $16 \mathrm{ml}$ equivalent to $20 \mathrm{mg}$ of zinc were placed in a flask. Hereinafter it was added to 
both flasks $10 \mathrm{ml}$ of a buffered solution of sodium tetraborate and sodium hydroxide and then $1 \mathrm{ml}$ of $1 \%$ resorcinol. Then, it was adjusted to $100 \mathrm{ml}$ and read at $490 \mathrm{~nm}$. Control solution was prepared without zinc. To calculate the concentration of zinc the following formula is used:

$\operatorname{zinc}(\mathrm{g} / \mathrm{L})=0.1 \times($ Absorbance of sample - absorbance of the control)

(Absorbance of sample and zinc - absorbance of sample)

The histrometrics mensurations of tubular diameter and height of the seminiferous epithelium, as well as the chemical determinations in accessory organs were analyzed by the statistical tests of Kruskal - Wallis.

\section{RESULTADOS}

Testicle: The administration of flutamide did not affect the value of TD among the groups (Table I). However, it caused a significant decrease in the height of the epithelium in the interval of $72 \mathrm{~h}(\mathrm{p}<0.005)$. In some seminiferous tubules the experimental group of $72 \mathrm{~h}$ showed detachment of the seminiferous epithelium, with presence of immature germinal cells.

Seminal vesicle: The concentration of fructose in the experimental groups diminished by $24 \mathrm{~h}$, but the values are not significant. At $72 \mathrm{~h}$ the concentration of fructose diminished in $42 \%$ with regard to the control $(\mathrm{p}<0.005)$.

Table I. Effect of the administration of flutamide in histometric testicular parameters.

\begin{tabular}{lcccc}
\hline & control & 24hours & 72hours & \\
\hline & $\mathrm{n}=6$ & $\mathrm{n}=4$ & $\mathrm{n}=5$ & $\mathrm{p}$ value \\
Tubular diameter $(\mu \mathrm{m})$ & $193 \pm 16$ & $178 \pm 11$ & $175 \pm 16$ & $\mathrm{p}>0.05$ \\
Epithelial height $(\mu \mathrm{m})$ & $61 \pm 4$ & $51 \pm 5$ & $50 \pm 3$ & $\mathrm{p}<0.005$ \\
\hline
\end{tabular}

Table II. Effect of the flutamide in the concentration of Fructose in Seminal Vesicle.

\begin{tabular}{|c|c|c|c|c|}
\hline & control & 24hours & 72 hours & \\
\hline & $\mathrm{n}=6$ & $\mathrm{~N}=4$ & $\mathrm{n}=5$ & p value \\
\hline Fructose $(\mathrm{mg} / \mathrm{ml})$ & $4,87 \pm 0,37$ & $3,77 \pm 1,09$ & $2,82 \pm 0,81$ & $\mathrm{p}<0.005$ \\
\hline
\end{tabular}

Table III. Effect of flutamide in the accumulation of Zinc in Prostate.

\begin{tabular}{ccccc}
\hline & control & 24hours & 72hours & \\
\hline & $\mathrm{n}=6$ & $\mathrm{~N}=4$ & $\mathrm{n}=5$ & $\mathrm{p}$ value \\
Zinc(g/1) & $0,332 \pm 0,01$ & $0,272 \pm 0,07$ & $3,79 \pm 1,97$ & $\mathrm{p}<0,01$ \\
\hline
\end{tabular}

Prostate: At 24 hours, the flutamide did not cause changes in the concentration of zinc. On the other hand, the group at $72 \mathrm{~h}$ presented elevated values of zinc $(1000 \%)$ with regard to the control $(\mathrm{p}<0.01)$.

\section{DISCUSSION}

Spermatogenesis: Through different investigations it has been concluded that the main role for $\mathrm{FSH}$ is in the proliferation of the spermatogonia. Many specific proteins are secreted by the Sertoli cells, among them is the protein $\mathrm{ABP}$, triggered by the binding of FSH to its receptor (Arrau et $a l$.). The synthesis of this factor would be influenced indirectly by testosterone. Testosterone may participate in the generation of receptors to FSH in Sertoli cells. (De Gendt et al., 2004).

In turn, the control of the development of the germinal cells could be determined by factors regulating Sertoli cells since in rats with knockout genes for AR in all tissues it is possible to develop only some germinal cells in the seminiferous tubule while the differentiated cells are not present (Yeh et al., 2002). In experiments carried out in rats with selective knockout genes for AR specific of Sertoli cells a $63 \%$ of germ cells is found, which would indicate a dependence of testosterone and of Sertoli cells (De Gendt et al.) in the last steps of the spermatogenic line. On the other hand, the myoid cells in answer to androgens stimulation secrete a molecule called PmodS that acts on the Sertoli cells regulating their activity (Norton et al., 1994).

In the rats with selective knockout a drastic decrease was observed in round espermatids (down to 3\%) and absence of elongated espermatids, even when testosterone exists in the lumen of the tubules (De Gendt et al. and Chang, 2004). This result shows that binding of testosterone to the receptor of Sertoli cells plays a crucial role in the development and differentiation of spermatocytes to elongated espermatids (De Gendt et al.; Chang and Meachem et al., 1997).

Zinc: The incorporation of zinc in prostate is regulated by androgen dependent mechanisms. It has been observed that a decrease in the levels of testosterone elevates the concentration of zinc in the epithelial cells of the ventral prostate (Costello et al.). Therefore, flutamide will have a positive effect in the intracellular levels of zinc.

Fructose: On the other hand the fructose is also regulated by androgens and it establishes a narrow relationship among the level of testosterone and fructose production by the seminal vesicle (Gonzales, 1989). Since the flutamide is a competitive inhibitor for AR one can assume that its effect is similar to the lack of testosterone, that is to say it provokes a decrease in the production of fructose, as it was expected and actually seen in this work. 
BUSTOS-OBREGÓN, E.; ESPONDA, P. \& SARABIA, L. Efecto de la flutamida en la espermatogénesis del ratón y en la función de la vesícula seminal y próstata. Int. J. Morphol., 24(2):171-174, 2006.

RESUMEN: La espermatogénesis está regulada por el eje hipotálamo-hipófisis-gónada, y los andrógenos juegan un rol fundamental en sus últimas etapas. La administración del antiandrógeno flutamida interfiere con ella y con la función de órganos andrógeno dependientes (próstata (P) y vesícula seminal (VS)). En este estudio se inyectó flutamida (10 mg/Kg peso corporal) a 10 ratones y vehículo al control(n=6). Los ratones se sacrificaron a las $24(n=5)$ y $72(n=5)$ horas. En cortes de testículo se midió el diámetro del túbulo (TD) y la altura del epitelio (EH). P y VS se maceraron, y se determinaron las concentraciones de fructosa (VS) y zinc (P). No existe diferencia significativa en el TD entre los grupos. Sin embargo, el grupo de $72 \mathrm{~h}$ presenta menor EH respecto al control (p<0.01). La fructosa es menor sólo a las $72 \mathrm{~h}(\mathrm{p}<0.01)$, intervalo en el cual se presenta la mayor concentración de zinc $(\mathrm{p}<0.01)$. La disminución de la EH se explicaría por el desprendimiento de las espermátidas elongadas, debido al bloqueo del efecto de la testosterona, sin reflejarse en el TD a intervalo corto. La disminución de fructosa refleja claramente la deprivación de andrógenos, en tanto que la concentración prostática aumentada a 72 hrs sugiere deficiencia en la secreción de zinc.

PALABRAS CLAVE: Flutamida; Ratón; Espermatogénesis; Vesícula seminal; Próstata.

\section{REFERENCES}

Arrau, J.; Bustos-Obregón, E.; Hoecker, G. \& Ramos, A. Biología de la Reproducción Animal. Andrés Bello, Santiago, 1975.

Brinkmann, A. O.; Blok, L. J.; de Ruiter, P. E.; Doesburg, P.; Steketee, K; Berrevoets, C. A. \& Trapman, J. Mechanism of androgen receptor activation and function. J. Steroid Biochemistry Molecular and Biology, 69:307-13, 1999.

Brodgen, R. N. \& Clissold, S. P. Flutamide. A preliminary review of its pharmacodynamic and pharmacokinetic properties, and therapeutic efficacy in advanced prostatic cancer. Drugs. 38(2):185-203, 1989.

Chang, C. Infertility with defective spermatogenesis and hypotestosteronemia in male mice lacking the androgen receptor in Sertol cells. PNAS USES 101(18):6876-81, 2004.

Costello, L. C.; Liu, Y.; Zou J. \& Franklin, R. B. Evidence for to Zinc Uptake Transporter in Human Prostate Cancer Cells which Is regulated by Prolactin and Testosterone. J. Biol. Chem., 274(25):17499-504, 1999.

De Gendt, K.; Swinnen, J. V.; Saunders, P. T.; Schoonjans, L.;Dewerchin, M.; Devos, A.; Tan, K.; Atanassova, N.; Claessens, F.; Lécureuil, Ch.; Heyns, W.; Carmeliet, P.; Guillou, F.; Sharpe, R. M., \& Verhoeven G. A Sertoli-cell selective knockout of the androgen receptor causes spermatogenesis arrest in meiosis. PNAS USES. 101(5): 1327-32, 2004.

Gonzales, G. F. Functional structure and ultrastructure of seminal vesicles. Arch. Androl., 22(1):1-13, 1989.

Gonzales, G. F. Manual de diagnostico y tratamiento de la pareja infértil. Ed. Peruvian University Cayetano Heredia, Lima, 1991.

Image Tool version 3.0 The University of Texas Health Science Center in San Antonio. http://ddsdx.uthscsa.edu/dig/itdesc.html
Meachem, S. J.; Wreford, N. G.; Robertson, D. M., \& McLachlan, R. I. Androgen action on the restoration of spermatogenesis in adult rats: effects of human chorionic gonadotrophin, testosterone and flutamide administration on germ cell number. Int. J. Androl., 20:70-9, 1997

Norton, J. N.; Vigne, J. L. \& Skinner, M. K. Regulation of Sertoli cell differentiation by the testicular paracrine factor PModS: analysis of common signal transduction pathways. Endocrinology, 134(1):149-57, 1994.

Steinberger, E. Hormonal regulation of the seminiferous tubule function. Curr.Top. Mol. Endocrinol., 2:337-52, 1975.

Viguier-Martínez, M. C. Endocrinological and histological changes induced by flutamide treatment on the hypothalamo-hypophyseal testicular axis of the adult male rat and their incidences on fertility. Records Endocrinol (Copenh), 104(2):246-52, 1983.

Wilson, C. \& McPhaul, M. A and B forms of the androgen receptor are expressed in a variety of human tissues. Mol. and Cell Endocrinol., 120:51-7, 1996.

Yeh, S.; Tsai, M.; Xu, O.; Mu, X.; Lardy, H.; Huang, K.; Lin, H.; Yeh, S.; Altuwaijri, S.; Zhou, X.; Xing, L.; Boyce, B. F.; Hung, M.; Zhang, S.; Gan, L. \& Chang, Ch. Generation and Characterization of androgen receptor knockout (ARKO) mice: and In Vivo model for the study of the androgen functions in selective tissues. PNAS USES 99(21):13489-503, 2002.

Correspondence to:

Prof. Dr. Eduardo Bustos-Obregón

Laboratory for Biology of Reproduction

Medical School

Universidad de Chile

Independencia 1027, P. O. Box 70061

Santiago 7-CHILE

Email:ebustos@med.uchile.cl

Received: 26-01-2006

Accepted: 12-03-2006 